\title{
Isolation of Latrodectus Venom and Proteomic Analysis of $\alpha$-Latrotoxin
}

\author{
Ankit Kumar Jain ${ }^{1 *}$, Dr. Vipulkeerti Sharma1, Dr. N.K. Dhakad ${ }^{2}$, Sachin Rahangdale ${ }^{3}$ \\ ${ }^{1}$ Government Holkar Science College, Indore, Madhya Pradesh, INDIA \\ ${ }^{2}$ Vice Chancellor D.A.V.V. Indore, Madhya Pradesh, INDIA \\ ${ }^{3}$ Govt. Madhav Science College, Ujjain, Madhya Pradesh, INDIA
}

\begin{abstract}
Many species of Spiders are venomous organisms, but the venoms of only a few species are wellunderstood, due to the difficulty associated with collecting minute quantities of venom from spiders. Venomous animals use a highly complex cocktails of proteins, peptides and small molecules to subdue and kill their prey. Structure-function studies of spider toxins are leading to the discovery of novel therapeutic routes for neuromuscular diseases, pain and to a variety of other pathological conditions. $\alpha$-Latrotoxin is a black widow spider (Latrodectus mactans) venom toxin causing massive neurotransmitter release. This paper presents a protocol for the isolation of venom from Latrodectus mactans using electrical stimulation. The isolated venom is useful for various further proteomic analyses including protein identification, functional assays, and stimulation of venom gene expression for transcriptomic studies. We have done molecular charecterization and modeled $\alpha-$ Latrotoxin structure using in silico Molecular Modeling Technique.
\end{abstract}

Keywords: Venom, $\alpha$-Latrotoxin, Latrodectus mactans, neurotransmitter, proteomic, in silico, Molecular Modeling.

\section{INTRODUCTION}

Scientific study of the venom, and its exploitation in research, began in the 1930s, when it was first discovered that the active ingredients of the venom were proteins (D'Amour et al., 1936), acting upon neurons (Sampayo, 1944). The best characterized of these is the vertebrate-specific toxin, $\alpha$-LTX (Grasso, 1976, Frontali et al., 1976). $\alpha$-Latrotoxin induces neurotransmitter release by stimulating synaptic vesicle exocytosis via two mechanisms: (1) $\mathrm{A} \mathrm{Ca}^{2+}$-dependent mechanism with neurexins as receptors, in which $\alpha$-latrotoxin acts like a $\mathrm{Ca}^{2+}$-ionophore, and (2) a $\mathrm{Ca}^{2+}$-independent mechanism with CIRL/Latrophilins as receptors, in which $\alpha$-latrotoxin directly stimulates the transmitter release machinery. $\alpha$-Latrotoxin is a large protein composed of an $\mathrm{N}$-terminal region containing disulfide bonds, and a C-terminal region containing 22 ankyrin repeats (Südhof, 2001, Ushkaryov et al., 2008). Latrodectus mactans, more commonly known as the southern black widow, are identified by their red and black coloring and are native to North America (Upadhyay \& Ahmad, 2011). They have historically been known as one of the most abundant toxin-bearing species of spiders in the US (Upadhyay \& Ahmad, 2011). Widow spiders are known for the severe potency of the neurotoxic venom, which contains a cocktail of various forms of the protein latrotoxin including $\alpha$-latrotoxin, $\alpha$ latrocrustatoxin, and $\alpha$ - latroinsectotoxin (Garb et al., 2004). Widow spiders (genus Latrodectus) have been documented as having a distribution that spans multiple continents and oceanic islands (Garb et al., 2004). This paper presents a protocol for the isolation of venom from black widow spiders, which can be applied to other spiders of same size. The isolation of venom separately from the spider enables identification of proteins that are secreted into the venom. Black widows and other Latrodectus species are widely recognized as being among the most hazardous spiders due to their highly neurotoxic venom, which causes severe pain in humans, which is sometimes accompanied by profuse sweating, muscle contractions, hypertension, difficulty breathing and patchy paralysis. The venom isolation protocol presented here uses electro-stimulation. The isolated venom has numerous uses, such as characterization and isolation of constituent molecules, for physiological experiments or functional assays, and to stimulate venom gene expression. We have used insilico approach for Protein sequence and identification of $\alpha$-Latrotoxin protein with the help of Uniprot, Characterization of $\alpha$-Latrotoxin protein and secondary structure composition from Protparam and PDB sum, Study of 
Families, Patterns and Profiles using Evolutionary trace server (trace suit server II), Structure prediction of $\alpha$-Latrotoxin protein with the help of Modeller, Phyre2, CPH Model, 2D Jigsa and Swiss Model and validation of predicted structure of $\alpha$-Latrotoxin protein by Rampage, Erate Plot, Savas and Mod loop.

\section{Methodology}

\subsection{Spider Collection and Isolation of Venom}

We have collected the spiders from Bagh, Tanda and Jobat (Madhya Pradesh, India). Fortunately we found a gravid female spider which lays eggs very soon so that we got enough individuals for experiment. We used following protocol to isolate the spider venom.

\subsubsection{Protocol}

\section{A. Preparation of Electro-Stimulator}

1. We set stimulator to the following initial settings: voltage $=7 \mathrm{~V}$, Frequency $=1$ pulses per second, delay $=0$ milliseconds, duration=200 milliseconds, twin pulses switch=regular and mode $\mathrm{switch}=$ off.

2. We tested output of electrodes by attaching alligator clips to voltmeter positive and negative test leads.

\section{B. Preparation of Forceps and Other Materials}

1. We dip one prong of forceps into liquid plastic coating and wait four hours to let coating dry. We tightly wrap $15 \mathrm{~mm}$ of the tip of the opposing prong with a single layer of cotton sewing thread. The thread is used to absorb an applied saline solution that promotes electrical conductivity, while the plastic coating provides insulation to retard current.

2. We cut tip of needle with sharp scissors and smooth the opening with sand paper.

3. We attached positive electrode alligator clip to forceps' bottom prong upstream of thread and attach negative alligator clip to blunt metal needle.

4. We prepared several microcapillary tubes for venom collection. Hold a single microcapillary tube at one end with a gloved hand and at the other end with sterile metal forceps, placing the forcepsheld end horizontally over a Bunsen burner flame. Pull on the microcapillary with the metal forceps away from the flame to create an elongated tip, while holding the other end in a stationary position.

\section{Immobilization of Spider in Forceps}

1. We used closed plastic vials as $\mathrm{CO}_{2}$ chamber and transfer spider into $\mathrm{CO}_{2}$ chamber using long metal forceps. As black widow spiders have hazardous venom we always wore gloves during this protocol.

2. We kept the spider in chamber until anesthetized and no longer moving when gently prodded with long forceps.

3. Retrieved anesthetized spider from $\mathrm{CO}_{2}$ chamber by picking it up by its anterior legs using blunt dissecting forceps and gloved hands. Moved anesthetized spider to featherweight forceps apparatus. Separated prongs of closed featherweight forceps and placed the spider's cephalothorax in between the prongs and allowed the prongs to close shut to ensure spider is held tightly in place but is not being crushed.

\section{Venom Collection}

1. We Turned on vacuum and spray spider chelicerae with water solution using a second blunt tipped syringe needle. Suction away water with vacuum needle to remove impurities.

2. Touched the vacuum needle with attached negative electrode to spider rostrum and delivered pulse one or more times. the venom appears as clear droplets emerging from fangs.

3. We Collected venom droplets with microcapillary tip and transfered capillary tip into $0.5 \mathrm{ml}$ tube with water (water sucked into capillary).

4. We Attached transfer syringe with tube adapter to microcapillary (at end opposite to collection tip) and dispensed venom solution back into tube. 


\subsection{Molecular Characterization}

We have done Protein sequence and identification of $\alpha$-Latrotoxin protein with the help of Uniprot database then Characterization of $\alpha$-Latrotoxin protein and secondary structure composition from Protparam and PDB sum tool.we have also done Study of Families, Patterns and Profiles using Evolutionary trace server (trace suit server II).

\subsection{Structure Prediction and its Validation}

We have done Structure prediction of $\alpha$-Latrotoxin protein with the help of Modeller, Phyre2, CPH Model, 2D Jigsa and Swiss Model and validation of predicted structure of $\alpha$-Latrotoxin protein by Rampage, Erate Plot, Savas and Mod loop.

\section{RESUlT AND DISCUSSION}

We have performed the collection of venom and venom gland to characterize venom proteins and peptides at the sequence level. Collected venom may also be used in physiological assays to determine their functional activities.

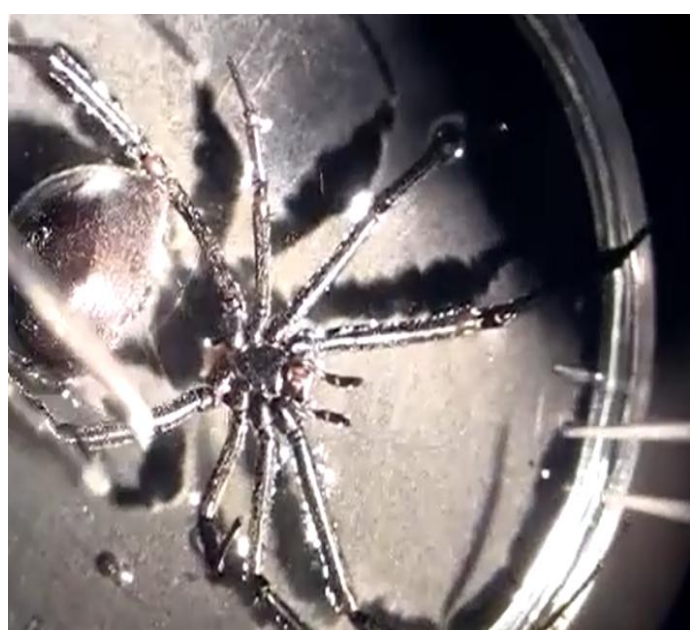

Fig1. Anesthetized Spider

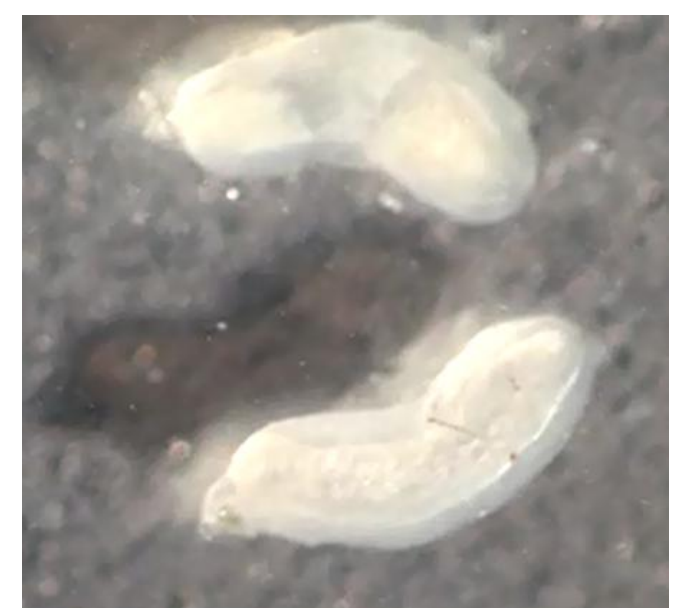

Fig2. Venom Glands

We have done Protein sequence and identification of $\alpha$-Latrotoxin protein with the help of Uniprot database.

Amino acid sequences of $\alpha$-Latrotoxin protein

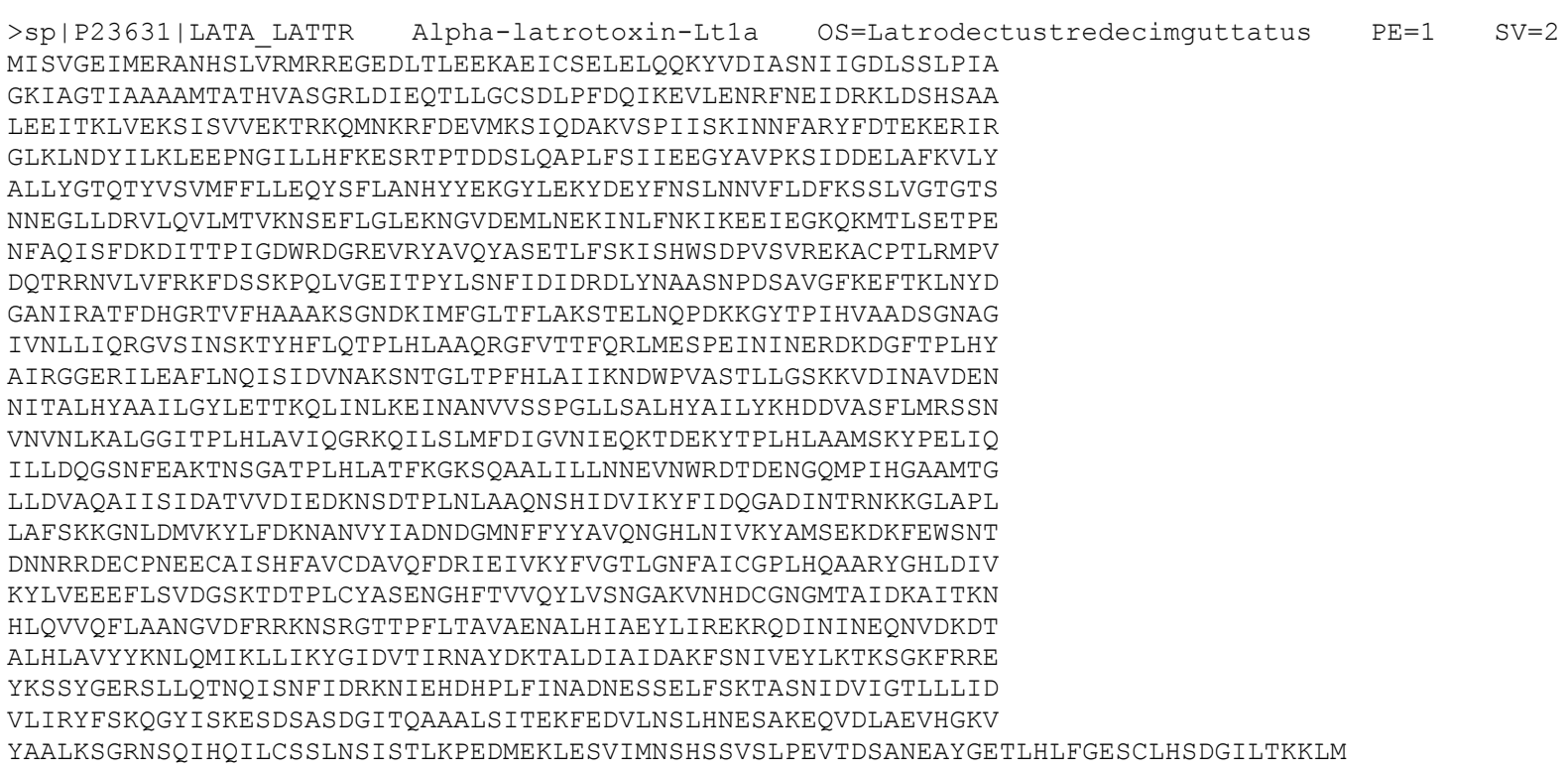

We have done Characterization of $\alpha$-Latrotoxin protein and secondary structure composition from Protparam and Emboss tool.

Molecular discripters of amion acid sequence of $\alpha$-Latrotoxin protein 
Ankit Kumar Jain et al.

Number of amino acids: 1401

Molecular weight: 156857.0

Theoretical pI: 5.61

Average Residue Weight $=111.961$

Charge $=-16.0$

Isoelectric Point $=5.7803$

A280 Molar Extinction Coefficients $=102000$ (reduced) 102625 (cystine bridges)

A280 Extinction Coefficients $1 \mathrm{mg} / \mathrm{ml}=0.650$ (reduced) 0.654 (cystine bridges) Improbability of expression in inclusion bodies $=0.521$

\section{Amino Acid Composition}

\begin{tabular}{|l|l|l|}
\hline Ala (A) & 108 & $7.7 \%$ \\
\hline Arg (R) & 51 & $3.6 \%$ \\
\hline Asn (N) & 97 & $6.9 \%$ \\
\hline Asp (D) & 91 & $6.5 \%$ \\
\hline Cys (C) & 11 & $0.8 \%$ \\
\hline Gln (Q) & 48 & $3.4 \%$ \\
\hline Glu (E) & 94 & $6.7 \%$ \\
\hline Gly (G) & 75 & $5.4 \%$ \\
\hline His (H) & 38 & $2.7 \%$ \\
\hline Ile (I) & 107 & $7.6 \%$ \\
\hline Leu (L) & 144 & $10.3 \%$ \\
\hline Lys (K) & 99 & $7.1 \%$ \\
\hline Met (M) & 26 & $1.9 \%$ \\
\hline Phe (F) & 61 & $4.4 \%$ \\
\hline Pro (P) & 37 & $2.6 \%$ \\
\hline Ser (S) & 103 & $7.4 \%$ \\
\hline Thr (T) & 74 & $5.3 \%$ \\
\hline Trp (W) & 5 & $0.4 \%$ \\
\hline Tyr (Y) & 50 & $3.6 \%$ \\
\hline Val (V) & 82 & $5.9 \%$ \\
\hline Pyl (O) & 0 & $0.0 \%$ \\
\hline Sec (U) & 0 & $0.0 \%$ \\
\hline
\end{tabular}

\begin{tabular}{|l|l|l|l|}
\hline Property & Residues & Number & \\
\hline Mole\% Tiny & $(\mathrm{A}+\mathrm{C}+\mathrm{G}+\mathrm{S}+\mathrm{T})$ & 371 & 26.481 \\
\hline Small & $(\mathrm{A}+\mathrm{B}+\mathrm{C}+\mathrm{D}+\mathrm{G}+\mathrm{N}+\mathrm{P}+\mathrm{S}+\mathrm{T}+\mathrm{V})$ & 678 & 48.394 \\
\hline Aliphatic & $(\mathrm{A}+\mathrm{I}+\mathrm{L}+\mathrm{V})$ & 441 & 31.478 \\
\hline Aromatic & $(\mathrm{F}+\mathrm{H}+\mathrm{W}+\mathrm{Y})$ & 154 & 10.992 \\
\hline Non-polar & $(\mathrm{A}+\mathrm{C}+\mathrm{F}+\mathrm{G}+\mathrm{I}+\mathrm{L}+\mathrm{M}+\mathrm{P}+\mathrm{V}+\mathrm{W}+\mathrm{Y})$ & 706 & 50.393 \\
\hline Polar & $(\mathrm{D}+\mathrm{E}+\mathrm{H}+\mathrm{K}+\mathrm{N}+\mathrm{Q}+\mathrm{R}+\mathrm{S}+\mathrm{T}+\mathrm{Z})$ & 695 & 49.607 \\
\hline Charged & $(\mathrm{B}+\mathrm{D}+\mathrm{E}+\mathrm{H}+\mathrm{K}+\mathrm{R}+\mathrm{Z})$ & 373 & 26.624 \\
\hline Basic & $(\mathrm{H}+\mathrm{K}+\mathrm{R})$ & 188 & 13.419 \\
\hline Acidic & $(\mathrm{B}+\mathrm{D}+\mathrm{E}+\mathrm{Z})$ & 185 & 13.205 \\
\hline
\end{tabular}

Total number of negatively charged residues (Asp + Glu): 185 total number of positively charged residues (Arg + Lys): 150 Atomic compositions:

$\begin{array}{lcc}\text { Carbon } & \text { C } & 6987 \\ \text { Hydrogen } & \text { H } & 11041 \\ \text { Nitrogen } & \text { N } & 1879 \\ \text { Oxygen } & \text { O } & 2144 \\ \text { Sulfur } & \text { S } & 37\end{array}$

Formula: $\mathrm{C}_{6987} \mathrm{H}_{11041} \mathrm{~N}_{1879} \mathrm{O}_{2144} \mathrm{~S}_{37}$

Total number of atoms: 22088 
MODELLER9.10 was used for 3D structure generation based on the information obtained from sequence alignment. The MODELLER software employs probability density functions as the spatial restraints rather than energy. The 3D model of a protein is obtained by optimization of the molecular such that the model violates the input restraints as possible. The molecule was derived as a combination of restraining individual spatial features of the whole molecule. Different automated servers for tertiary protein structure were utilized such as Phyre2, Protein Jigsaw, I-tasser.

Protein was modeled and validated by using the SAVS server. Ramachandran plots were drawn and the structures were analyzed by PROCHECK, a well-known protein structure checking program. By comparison of the results for all the models from different servers and from Modeller9.10, each structure above $82 \%$ accuracy was selected in order to run optimized protein dynamics with their respective simulation. All these findings suggest a stereochemically very good model. The overall PROCHECK $G$ factor for the homology-modeled structure was 1.00 and resolution was 1.5 . The final structure was validated by an ERRAT graph. The quality factor of 77.106 indicated good quality, as scores of $>50$ are acceptable for a reasonable model. High quality of model is also confirmed from VERIFY 3D server as $65.00 \%$ of residues of modeled protein showed a score higher than 0.2 thus the model showed satisfactory 3D-1D scores for all the residues in the sequence.
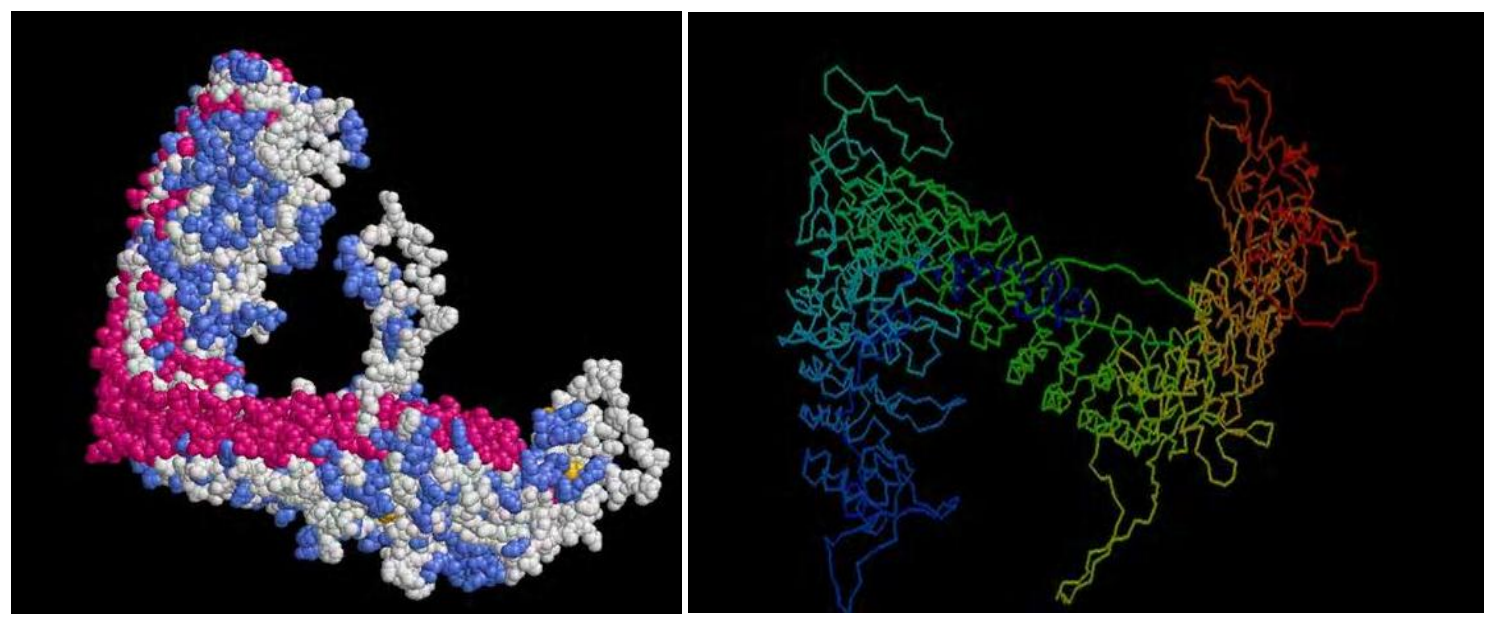

Fig3. $3 D$ Structure of $\alpha$-Latrotoxin protein

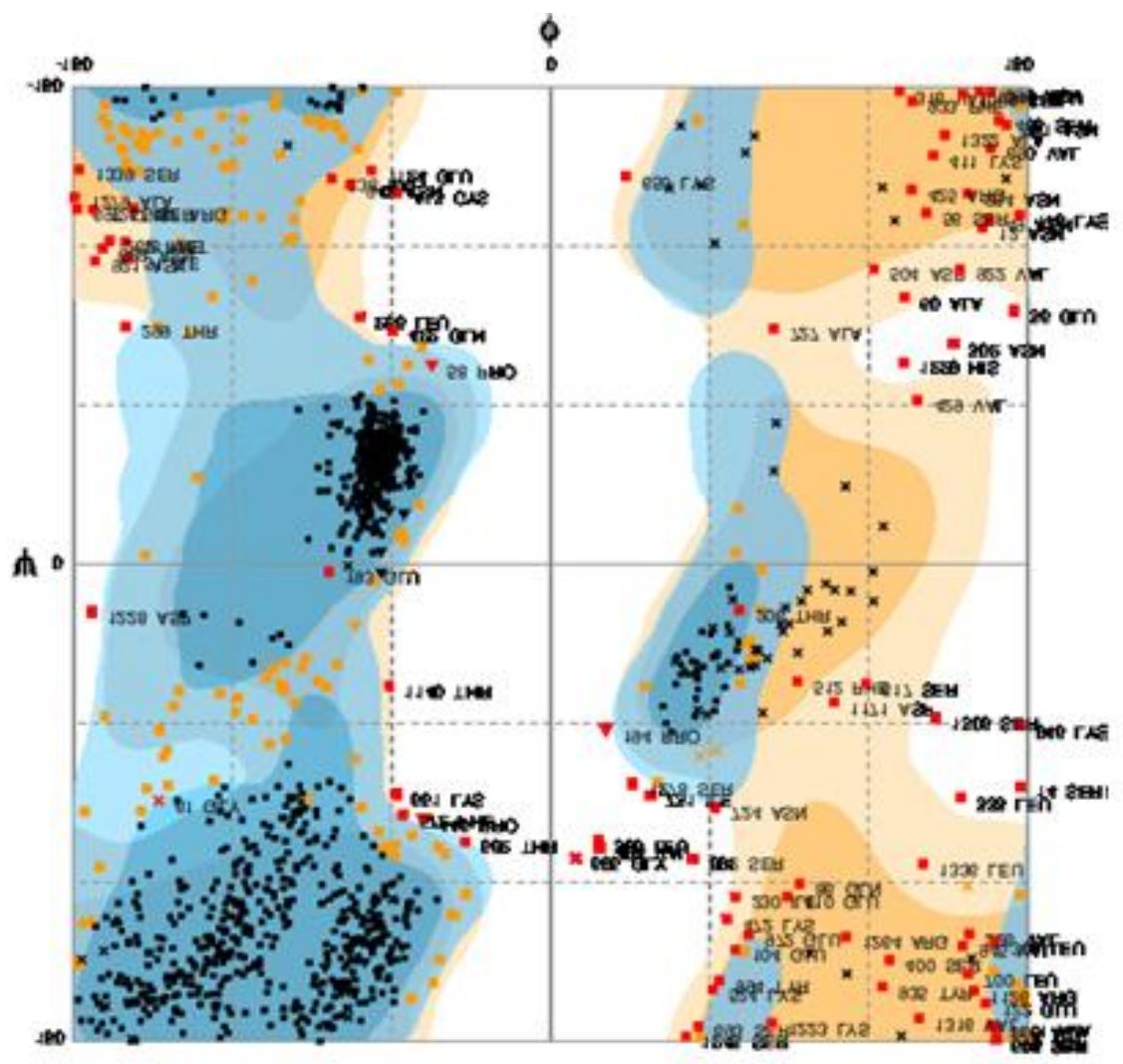


Evaluation of residues

Number of residues in favoured region ( 98.0\% expected): 1157 (82.7\%)

Number of residues in allowed region ( 2.0\% expected): 149 (10.7\%)

Number of residues in outlier region: 93 (6.6\%)

\section{Conclusion}

Even though the effect of toxin application in various systems is obvious and well documented, the molecular machinery underlying its mode of action are still highly debated and controversial. $\alpha$-LTX is a naturally occurring highly poisonous agent which is used by black widow spiders to inflict excruciating pain and scare away its enemy (a vertebrate animal). It is, therefore, not surprising that the toxin's effects are so powerful and diverse, while its mechanisms (including its targeting of multiple receptors and several modes of actions) are so complex. Nevertheless, the $\alpha$-LTX studies have led to the formulation of extremely important scientific concepts. It now appears obvious that neurotransmitter release occurs via exocytosis.

Venoms represent an important source of physiologically reactive proteins, peptides and other molecules with applications for drug discovery, as well as for fundamental aspects of cellular research. However, the collection of venom, particularly from dangerous or small animals, is a challenging task. This protocol demonstrates how venom and venom glands can be collected from black widow spiders. In conclusion, this article provides a verified protocol to obtain spider venom and venom glands. Venom and venom glands allow for the isolation and characterization of their protein and peptide components using proteomic and transcriptomic approaches. In addition, venom samples may represent the starting point of functional assays, which determine the biomedical and pharmacological potential of their constituent molecules.

Widow spiders are known for the severe potency of the neurotoxic venom, which contains a cocktail of various forms of the protein latrotoxin including $\alpha$-latrotoxin, $\alpha$-latrocrustatoxin, and $\alpha$ latroinsectotoxin. A comparison of the structure of the different latrotoxin proteins revealed an average of $30 \%$, identical amino acid residues. This high homology suggests these proteins likely evolved by gene duplication. All latrotoxins, $\alpha$-latrotoxin included, trigger neurotransmitter release in organisms they are active in.

$\alpha$-latrotoxin is a large $\sim 156 \mathrm{kDa}$ hydrophilic protein that targets neural and neuroendocrine nerve terminals to cause large amounts of spontaneous neurotransmitter release We have done molecular characterization of amino acid composition of $\alpha$-latrotoxin protein. We have modeled and simulated $\alpha$-latrotoxin protein structure and identified $\alpha$-latrotoxin as a strong and very dynamic structure which can be utilized as a carrier for development of new strategies at proteomic level.

\section{REFERENCES}

D'Amour F, Becker FE, van Riper W (1936) the black widow spider. Q Rev Biol 11: 123-160.

Frontali N, Ceccarelli B, Gorio A, Mauro A, Siekevitz P, Tzeng MC, Hurlbut WP (1976) Purification from black widow spider venom of a protein factor causing the depletion of synaptic vesicles at neuromuscular junctions. J Cell Biol 68: 462-479.

Frontali N, Granata F, Parisi P (1972) Effects of black widow spider venom on acetylcholine release from rat cerebral cortex slices in vitro. Biochem. Pharmacol 21: 969-974.

Garb J, González A, Gillespie G (2004) the black widow spider genus Latrodectus (Araneae: Theridiidae): phylogeny, biogeography, an invasion history. Molecular Phylogenetics and Evolution 31: 1127-1142.

Garb J, Hayashi C (2013) Molecular Evolution of $\alpha$-Latrotoxin the Exceptionally Potent Vertebrate Neurotoxin in Black Widow Spider Venom. Molecular Biology and Evolution 30 5: 999-1014.

Grasso A (1976) Preparation and properties of a neurotoxin purified from the venom of black widow spider (Latrodectus mactans tredecimguttatus). Biochim Biophys Acta 439: 406-412.

Grasso A, Alema S, Rufini S, et al (1980) Black widow spider toxin-induced calcium fluxes and transmitter release in a neurosecretory cell line. Nature 283: 774-776.

Grasso A, Mercanti-Ciotti MT (1993) the secretion of amino acid transmitters from cerebellar primary cultures probed by $\alpha$-latrotoxin. Neuroscience 54: 595-604. 
Grasso A, Pelliccia M, Alema S (1982) Characterization of $\alpha$-latrotoxin interaction with rat brain synaptosomes and PC12 cells. Toxicon 20: 149-156.

Grasso A, Rufini S, Senni I, Concanavalin A (1978) blocks black widow spider toxin stimulation of transmitter release from synaptosomes. FEBS Lett 85: 241-244.

Sampayo RRL (1944) Pharmacological action of the venom of Latrodectus mactans and other Latrodectus spiders. J Pharmacol Exp Ther 80: 309-322.

Südhof TC (2001) $\alpha$-Latrotoxin and its receptors neurexins and CIRL/latrophilins. Annu Rev Neurosci 24: 933-962.

Südhof TC (2004) the synaptic vesicle cycle. Annu Rev Neurosci 27: 509-547.

Südhof TC, Rothman JE (2009) Membrane fusion grappling with SNARE and SM proteins. Science 323: 474-477.

Upadhyay R, Ahmad S (2011) A review on spider toxins a useful source of pharmacological peptides. Journal of Pharmacy Research 4: 1169-1172.

Ushkaryov YA, Petrenko AG, Geppert M, Südhof TC (1992) Neurexins synaptic cell surface proteins related to the alpha-latrotoxin receptor and laminin. Science 257: 50-56.

Ushkaryov YA, Rohou A, Sugita S (2008) $\alpha$-Latrotoxin and its receptors. Handb Exp Pharmacol : 171- 206.

Ushkaryov YA, Volynski KE, Ashton AC (2004) The multiple actions of black widow spider toxins and their selective use in neurosecretion studies. Toxicon 43: 527-542.

\section{AUTHOR'S BIOGRAPHY}

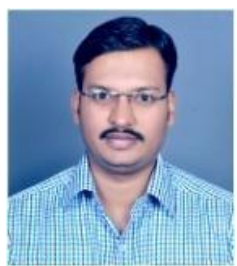

Ankit Kumar Jain, Currently working as a research scholar department of Zoology Govt. Holkar Sciences College Indore (M.P). Have qualified NET and GATE. More than 4 research paper have been published in reputed national and international Journals. The field of research is Molecular docking, Protein-Protein Interaction and Molecular Modeling. I have also attended the national and International Seminar, Conferences and Workshop. 